Down Syndrome Research and Practice Vol. 6, No. 1, pp 25-42

(C) The Down Syndrome Educational Trust

Printed in Great Britain. All Rights Reserved.

ISSN: 0968-7912 (1999) 6:1

\title{
DOWN SYNDROME AND THYROID DISORDERS: A REVIEW
}

\author{
V. P. Prasher \\ Department of Psychiatry, University of Birmingham, UK
}

\begin{abstract}
Thyroid disorders are common in the Down syndrome population but many specific areas of importance remain to be resolved. A detailed review of previously published case reports and research studies highlighting the clinical association between Down syndrome and thyroid disorders was undertaken. Historical, epidemiological, immunological, diagnostic and treatment issues are addressed. Recommendations for future management and research are considered.
\end{abstract}

Keywords: Down syndrome, thyroid disorders, review

\section{Introduction}

Down syndrome is the single most common cause of severe learning disability, accounting for about one third of all cases of learning disability (Alberman, 1978). Seguin in 1866 described the condition now known as Down syndrome as "furfuraceous" cretinism, in an attempt to differentiate the condition from that of "stable" cretins. Unintentionally, therefore, over onehundred and thirty years ago a link between Down syndrome and thyroid disease had been proposed. Langdon-Down (1866), influenced by the then prevalent "racial hypothesis" described the condition as "mongolism" and thought that affected people were a form of regression in evolution. During the early part of this century other endocrine disorders were implicated in the aetiology of Down syndrome. Some authors suggested that pituitary dysfunction was the main factor in the pathogenesis (Myers, 1938; Benda, 1946). The matter was finally resolved when in 1959 Lejeune and his co-workers (Lejeune et al, 1959) demonstrated that the syndrome was a result of trisomy of chromosome 21 .

At the turn of the century, a pathological association between Down syndrome and thyroid disorders was described by Bournville (1903). Clinical and histo-pathological confirmation soon followed (Hill, 1908; Gordon, 1930;

Pennacchietti, 1935; Benda, 1949). However, the first case of a person with Down syndrome and clinical hyperthyroidism was reported by Gilchrist in 1946 and of clinical hypothyroidism by Maranon et al, in 1951. At the turn of the third millennium thyroid disease in the Down syndrome population continues to be the focus of ongoing interest and research (Kennedy et al, 1992). This review collates previous research in the area of thyroid disorder and Down syndrome and explores aspects in need of further enquiry.

\section{Prevalence studies}

Over the last 30 years many publications have suggested an association between Down syndrome and thyroid disorders by showing altered levels of abnormal thyroxine (T4), triiodothyronine (T3) and/or thyroid stimulating hormone (TSH) levels (Table 1). Such changes may be present along with other hormonal and biochemical disturbances (Hestnes et al, 1991).

There is a wide variation in reported prevalence rates of thyroid disorders in the Down syndrome population. Differences can be accounted for by the variability in the definitions of thyroid disorders employed in different studies, by the different populations (size, age) studied and by techniques used to measure given hormones and antibodies. Definitions or research diagnostic operational criteria for terms such as

"hypothyroidism" are, therefore, useful; one such classification is shown in Table 2.

Hillman (1969) found that none of his 35 patients had thyroid dysfunction; Baxter et al (1975) found a rate of $66 \%$ in a sample size of eleven people with Down syndrome. Most studies report a prevalence rate higher than that 
Table 1: Studies of prevalence of Down syndrome and thyroid disorder

\begin{tabular}{|c|c|c|c|c|c|c|}
\hline Author (ref) & Year & $\begin{array}{l}\text { No. of } \\
\text { subjects } \\
\text { in study }\end{array}$ & $\begin{array}{c}\text { Age } \\
\text { range } \\
\text { (years) }\end{array}$ & $\mathbf{M} / \mathbf{F}$ & $\begin{array}{c}\text { No. of } \\
\text { patients } \\
\text { with thyroid } \\
\text { dysfunction (no) }\end{array}$ & $\begin{array}{c}\text { Abnormalities } \\
\text { in one or more } \\
\text { values of } \\
\text { T4/T3/Tsh* (\%) }\end{array}$ \\
\hline Pearse et al & 1963 & 151 & $6-21$ & - & 25 & 17 \\
\hline Hillman & 1969 & 35 & $12-39$ & $24 / 11$ & 0 & 0 \\
\hline Hollingsworth et al & 1974 & 60 & $9-65$ & $39 / 21$ & 17 & 28 \\
\hline Piffanelli et al & 1974 & 73 & $6-24$ & & 15 & 21 \\
\hline Baxter et al & 1975 & 11 & $44-65$ & $6 / 5$ & 7 & 66 \\
\hline Murdoch et al & 1977 & 82 & $19-65$ & $44 / 38$ & 34 & 41 \\
\hline Sare & 1978 & 121 & $13-48$ & $81 / 40$ & 23 & 20 \\
\hline Korsager et al & 1978 & 24 & $41-60$ & $8 / 16$ & 10 & 42 \\
\hline Quinn & 1980 & 49 & $8-59$ & - & 3 & 6 \\
\hline Lobo et al & 1980 & 101 & $5-47$ & - & 7 & 7 \\
\hline Samuel et al & 1981 & 54 & 9-12 days & $20 / 34$ & 10 & 18 \\
\hline Hughes et al & 1982 & 38 & $16-65$ & $27 / 11$ & 8 & 21 \\
\hline Vladutiu et al & 1984 & 42 & $18-64$ & $22 / 20$ & 23 & 55 \\
\hline Fort et al & 1984 & 1130 & 3-16 days & - & 12 & 0.12 \\
\hline Ziai et al & 1984 & 62 & $5-16$ & $40 / 22$ & 7 & 11 \\
\hline Coleman \& Abbassi & 1984 & 206 & $<18$ & - & 16 & 8 \\
\hline Pueschel \& Pezzullo & 1985 & 151 & $3-21$ & $92 / 59$ & 41 & 27 \\
\hline Cutler et al & 1986 & 49 & $4 / 12-3$ & $24 / 25$ & 18 & 37 \\
\hline Kinnell et al & 1987 & 111 & $22-72$ & $56 / 55$ & 16 & 14 \\
\hline Mani & 1988 & 55 & $24-67$ & $32 / 23$ & 12 & 22 \\
\hline Sharav et al & 1988 & 147 & $4 / 12-27$ & - & 88 & 60 \\
\hline Tirosh et al & 1989 & 44 & $2-51$ & $31 / 14 ?$ & 9 & 20 \\
\hline Dinani \& Carpenter & 1990 & 106 & $20-67$ & $61 / 45$ & 43 & 41 \\
\hline Zori et al & 1990 & 61 & $5 / 12-48$ & $34 / 27$ & 40 & 66 \\
\hline Pozzan et al & 1990 & 108 & $3 / 12-38$ & $55 / 53$ & 40 & 37 \\
\hline Suresh \& Robertson & 1993 & 69 & $22-69$ & $42 / 25$ & 23 & 33 \\
\hline Prasher & 1994 & 160 & $17-76$ & 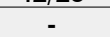 & 56 & 35 \\
\hline Pueschel et al & 1991 & 181 & $<30$ & $104 / 77$ & 29 & 16 \\
\hline Toledo et al & 1997 & 105 & $3 / 12-20$ & $50 / 55$ & 54 & 51 \\
\hline Rooney \& Walsh & 1997 & 136 & $10-56$ & - & 18 & 13 \\
\hline Jaruratansirikul et al & 1998 & 112 & $<1$ & - & 17 & 15 \\
\hline
\end{tabular}

Modified from Prasher (1994).

*(T4 = Thyroxine; T3 = Tri idothyronine; TSH = Thyroid Stimulating Hormone $)$.

Table 2: Operational criteria for thyroid disorders.

\begin{tabular}{|l|c|c|}
\hline & FREE T4 & TSH \\
\hline HYPOTHYROIDISM & Low $(<9 \mathrm{pmo} 1 / 1)$ & High $(>5 \mathrm{mU} / 1)$ \\
\hline $\begin{array}{l}\text { HYPOTHYROIDISM } \\
\text { (subclinical/compensated) }\end{array}$ & Normal $(9-24 \mathrm{pmo1} / 1)$ & High $(>5 \mathrm{mU} / 1)$ \\
\hline HYPERTHYROIDISM & High $(>9 \mathrm{pmol} / 1)$ & Low $(<0.5 \mathrm{mU} / 1)$ \\
\hline
\end{tabular}

FREE T4 = free Thyroxine, TSH = Thyroid Stimulating Hormone

(Reference: Parle et al 1991)

in the general population. An evaluation of reported studies would suggest a lifetime prevalence of approximately $25-30 \%$.

Tunbridge et al, (1977) found the prevalence of hypothyroidism in the general population (aged 18 years and older), to be $0.8 \%-1.1 \%$, and the prevalence of hyperthyroidism as $1.1 \%-1.6 \%$. A large study of congenital hypothyroidism in neonates with Down syndrome reported a prevalence of $0.12 \%$; twenty-eight times greater than for the general population (Fort et al, 1984). The prevalence of acquired thyroid disorders increases with age, with higher rates being found for older persons with Down syndrome (Baxter et al, 1975; Korsager et al, 1978; Vladutiu et al, 1984; Dinani \& Carpenter, 1990).

The prevalence of hypothyroidism has been found to be greater than that of hyperthyroidism. A ratio of $9 \%$ to $2 \%$ was proposed by Kinnell et al, (1987). Prasher (1994) investigated thyroid dysfunction in 160 adults with Down syndrome (mean age 43.4 years; age range 17-76 years). 
Thirty-five percent had evidence of thyroid dysfunction; subclinical hypothyroidism $12 \%$, definite hypothyroidism $8 \%$, hyperthyroidism $3 \%$.

As well as an increase in the prevalence of hormonal abnormalities there is also an increased prevalence of autoimmune thyroiditis. Coleman and Abbassi (1984) found lymphocytic thyroiditis in 15 of 16 patients. Ivarsson et al (1997) found 39\% of their sample of 70 children positive for thyroid antibodies and Vladitiu (1984) 38\% of adults with Down syndrome.

Detailed discussion on immunological aspects of Down syndrome is given later (see

"immunological aspects"). In view of these findings children and adults with Down syndrome should be regularly tested for thyroid hormone and antibody status (see "management of thyroid disorders").

\section{Reports of hypothyroidism and hyperthyroidism}

As mentioned above, hypothyroidism is the commonest form of thyroid disorder associated with Down syndrome. The first case report of such an association was by Maranon et al (1951); this and the succeeding reports are listed in Table 3. Prevalence studies have shown that older individuals with Down syndrome are more prone to hypothyroidism, although most of the reports describe individuals below the age of 20 years and only one report is of a person over the age of 50 years. The female: male ratio is approximately 2:1.

Hypothyroidism may be either congenital (present at birth e.g. Verma \& Ghal, 1971; King et al, 1978) or be acquired (occur at any age after birth). The neonatal screening programme

\begin{tabular}{|c|c|c|c|c|c|}
\hline AUTHOR (Ref) & YEAR & AGE & SEX & KARYOTYPE & OTHER CONDITIONS \\
\hline Maranon et al & 1951 & 12 & $M$ & - & Early Puberty \\
\hline Talbot et al & 1952 & $10 / 12$ & $\mathrm{~F}$ & - & - \\
\hline Esen \& Mautner & 1957 & 6 & $\mathrm{~F}$ & - & - \\
\hline Lunde & 1959 & 9 & $F$ & T21 & - \\
\hline Hubble & 1963 & 5 & $\mathrm{~F}$ & T21 & Early Puberty \\
\hline Mellon et al & 1963 & 29 & $\mathrm{~F}$ & T21 & - \\
\hline Hayles et al & 1965 & 13 & $\mathrm{~F}$ & - & Early Puberty \\
\hline Pabst & 1967 & 8 & $\mathrm{~F}$ & T21 & Early Puberty \\
\hline Matsaniotis et al & 1967 & 6 & M & T21 & Seminoma \\
\hline Harris \& Koutsouleris & 1967 & 3 & $\mathrm{~F}$ & T21 & - \\
\hline Daniels \& Simon & 1968 & 17 & M & T21 & Diabetes Mellitus \\
\hline Litman & 1968 & 1 & $M$ & T21 & Diabetes Mellitus \\
\hline Fliegelman \& Reisman & 1968 & 9 & $\mathrm{~F}$ & T21 & Early Puberty \\
\hline \multirow[t]{2}{*}{ Aarskog } & 1969 & $15 / 12$ & $\mathrm{~F}$ & T21 & - \\
\hline & & 9 & $\mathrm{~F}$ & T21 & Early Puberty \\
\hline Verma \& Ghal & 1971 & 2 days & $M$ & - & - \\
\hline \multirow[t]{3}{*}{ Williams et al } & 1971 & 3 & $M$ & T21 & - \\
\hline & & 14 & $M$ & T21 & - \\
\hline & & 17 & M & T21 & Early Puberty \\
\hline Costin et al & 1972 & 8 & $\mathrm{~F}$ & - & Early Puberty \\
\hline Shaheed \& Rosenbloom & 1973 & 6 & $\mathrm{~F}$ & T21 & Diabetes Mellitus \\
\hline Zergollern et al & 1974 & $3 / 12$ & $M$ & T21 & - \\
\hline Tonz \& Trost & 1974 & 16 & $\mathrm{~F}$ & T21 & Early Puberty \\
\hline Parkin & 1974 & 5 & $\mathrm{~F}$ & T21 & Diabetes Mellitus \\
\hline Ong \& Schneider & 1976 & 13 & $\mathrm{~F}$ & T21 & Diabetes Mellitus \\
\hline King et al & 1978 & 13 days & $\mathrm{F}$ & T21 & - \\
\hline Floret et al & 1978 & 9 & $\mathrm{~F}$ & T21 & Early Puberty/Alopecia Areata \\
\hline Stein \& Jewell & 1979 & 33 & $\mathrm{~F}$ & - & Diabetes Mellitus \\
\hline Thase & $1982 b$ & 38 & $\mathrm{~F}$ & T21 & Reversible Dementia \\
\hline Radetti et al & 1986 & 17 & $\mathrm{~F}$ & T21 & Diabetes Mellitus \\
\hline Heydarian et al & 1987 & 9 & $\mathrm{~F}$ & - & Death from cardiac tamponade \\
\hline Schindler & 1989 & 10 & $\mathrm{~F}$ & - & - \\
\hline Scotson & 1989 & 27 & $M$ & T21 & Alopecia \\
\hline Prasher \& Krishnan & 1993 & 55 & $\mathrm{~F}$ & $\mathrm{~T} 21$ & Dementia \\
\hline \multirow[t]{3}{*}{ Werder et al } & 1993 & 9 & $\mathrm{~F}$ & T21 & Pericardial effusion \\
\hline & & 12 & M & T21 & Pericardial effusion \\
\hline & & 9 & $\mathrm{~F}$ & T21 & Pericardial effusion \\
\hline Feliz de Vargas Pastor et al & 1993 & 10 & $\mathrm{~F}$ & T21 & Pericardial effusion \\
\hline Dura et al & 1995 & 13 & $\mathrm{~F}$ & - & - \\
\hline Fargas et al & 1996 & $13 / 12$ & $\mathrm{~F}$ & - & Pericardial effusion \\
\hline
\end{tabular}

Modified from Prasher (1995). 
by Fort et al (1984) found an incidence of congenital hypothyroidism of 1:141 live births (12 infants who had hypothyroidism out of 1130 live births). Three of the 12 infants with Down syndrome had transient hypothyroidism which resolved without intervention. Jaruratanasirikul et al (1998) detected congenital hypothyroidism in 17 of $112(15 \%)$ babies with Down syndrome less than 1 year old. The majority had transient hypothyroidism. Thorpe-Beeston et al (1991) reported raised thyroxine stimulating hormone
Gilchrist (1946) described the first case of a person with Down syndrome with a goitre secondary to hyperthyroidism. Table 4 lists other reports. Similar to case reports for persons with Down syndrome and hypothyroidism the majority of reports concern young individuals. There appears to be a greater female than male preponderance for hyperthyroidism than for hypothyroidism.

Table 4: Case reports of Down syndrome and hyperthyroidism

\begin{tabular}{|c|c|c|c|c|c|}
\hline AUTHOR (Ref) & YEAR & $\begin{array}{l}\text { AGE } \\
\text { (YRS) }\end{array}$ & SEX & KAROTYPE & $\begin{array}{l}\text { COMMENTS/OTHER } \\
\text { CONDITIONS }\end{array}$ \\
\hline Gilchrist & 1946 & 22 & $F$ & - & - \\
\hline McGirr \& Murray & 1956 & 23 & $F$ & - & - \\
\hline Esen \& Mautner & 1957 & 15 & $\mathrm{~F}$ & - & - \\
\hline Dupuy \& Madrigal & 1957 & 15 & $\mathrm{~F}$ & - & - \\
\hline Diggle \& Weetch & 1958 & 6 & $F$ & - & - \\
\hline Nickey & 1960 & 12 & $\mathrm{~F}$ & - & - \\
\hline \multirow[t]{2}{*}{ Abrahamsen } & (1961) & 21 & $\mathrm{~F}$ & - & - \\
\hline & & 41 & $F$ & - & - \\
\hline \multirow[t]{2}{*}{ Johnson \& Cook } & (1962) & 14 & $\mathrm{~F}$ & - & - \\
\hline & & 36 & $M$ & - & - \\
\hline Timbury et al & (1963) & 29 & $\mathrm{~F}$ & - & - \\
\hline \multirow[t]{3}{*}{ Kay \& Esselborn } & (1963) & 9 & $\mathrm{~F}$ & T21 & -? latrogenic \\
\hline & & 13 & $F$ & - & Diabetes Mellitus \\
\hline & & 13 & $\mathrm{~F}$ & - & ? latrogenic/Diabete Mellitus \\
\hline Hayles et al & (1965) & 14 & $\mathrm{~F}$ & - & - \\
\hline Ansari \& Schneesbery & (1967) & 26 & $\mathrm{~F}$ & - & Sister had thyroidectomy \\
\hline Subrt et al & (1968) & 6 & M & T21 & Diabetes Mellitus \\
\hline \multirow[t]{2}{*}{ Aarskog } & (1969) & 7 & $\mathrm{~F}$ & $\mathrm{D} / \mathrm{G}$ & - \\
\hline & & & & Translocation & \\
\hline \multirow[t]{2}{*}{ Azizi et al } & (1974) & 11 & $F$ & - & \\
\hline & & 23 & $\mathrm{~F}$ & - & Mother had thyroidectomy \\
\hline Morton \& Jenkins & (1978) & 10 & $\mathrm{~F}$ & - & - \\
\hline \multirow[t]{3}{*}{ Takahashi et al } & (1979) & 12 & $\mathrm{~F}$ & & \\
\hline & & 13 & $\mathrm{~F}$ & T21 & ? latrogenic \\
\hline & & 15 & $\mathrm{~F}$ & - & CCF \\
\hline Nibhanupudy et al & (1986) & 27 & $\mathrm{~F}$ & - & -1 \\
\hline Blumberg \& Tuskin & (1987) & 13 & M & T21 & Hypoparathyroidism \\
\hline Crespo \& Cuadrado et al & (1996) & 8 & $\mathrm{~F}$ & - & Celiac disease. \\
\hline \multirow[t]{2}{*}{ Bhowmick \& Grubb } & (1997) & 12 & $\mathrm{~F}$ & - & - \\
\hline & & 9 & $M$ & - & Diabetes Mellitus \\
\hline
\end{tabular}

\section{Modified from Prasher (1995).}

levels in all of the 5 fetuses with Down syndrome that they studied. Whether such an abnormality is involved in the subsequent development of learning disability and the possible value of intrauterine thyroid hormone supplementation remains to be studied. The aetiology of acquired hypothyroidism remains uncertain, although it is probably secondary to auto-immune thyroiditis (see "immunological aspects").

\section{Clinical features of thyroid disorders in Down syndrome}

Common features of hypothyroidism and hyperthyroidism are listed in Table 5.

In the past, similarities between Down syndrome and hypothyroidism led to misdiagnosis (Shuttleworth, 1909) and to subsequent inappropriate treatment of Down syndrome with thyroid extract (Benda, 1949). Smith (1896) is reported to be the first physician to treat the condition of "mongolism"with thyroid extract.

Recognition of thyroid disorders (especially hypothyroidism), can be very difficult; the 
person with Down syndrome is usually shorter in height, appears less active, has dry skin and fine hair, excess weight, bradycardia and mental impairment. These features are seen in hypothyroidism (Table 5) and therefore, make the early clinical diagnosis of hypothyroidism in individuals with Down syndrome difficult (Korsager \& Andersen, 1979; Quinn, 1980; Mani, 1988, Prasher, 1995).

Table 5. Common features of hypothyroidism and hyperthyroidism

\begin{tabular}{|c|c|}
\hline Hypothyroidism & Hyperthyroidism \\
\hline tiredness & weight loss \\
\hline weight gain & behavioral problems \\
\hline slowing & irritable \\
\hline cold hands & restlessness \\
\hline loss of memory & tremor \\
\hline change in mood & diarrhoea \\
\hline puffy face & goitre \\
\hline dry, brittle hair & confusion \\
\hline dry, coarse skin & palpitations \\
\hline constipation & heat intolerance \\
\hline & \\
\hline
\end{tabular}

Mani (1988) in his study found that approximately $50 \%$ of 55 adult Down syndrome residents had clinical features suggestive of hypothyroidism (12\% strong evidence, $38 \%$ mild evidence), and no cases of hyperthyroidism. Biochemically, however, only $22 \%$ had evidence of hypothyroidism (8 overt and 4 mild or subclinical). Prasher (1995) investigated the accuracy of diagnosing hypothyroidism in 201 adults with Down syndrome. Biochemical thyroid status was available for 160 subjects. For this group 57 were diagnosed has having clinical hypothyroidism but only 8 had underlying biochemical abnormalities. Five individuals with definite biochemical hypothyroidism showed no clinical evidence fore the disorder. A poor correlation between clinical hypothyroidism and biochemical hypothyroidism was found.

Neonatal screening tests for diagnosis of congenital hypothyroidism, although routinely done after birth, may not give an accurate reflection of thyroid function because of the TSH surge soon after birth. Clinical correlation with the tests could be spurious as the signs and symptoms of hypothyroidism in the new-born are not well developed. However, prolongation of physiological icterus, feeding difficulties, sluggishness, lack of interest, somnolescence and choking spells during nursing could be present during the first month. Respiratory problems due to large tongue, episodes of apnoea, noisy respiration and nasal obstruction could point towards a hypothyroid state in older infants. Affected infants cry little, sleep more, have poor appetite and show general sluggishness. Presence of an umbilical hernia, subnormal temperature and slow pulse point to the diagnosis of hypothyroidism in children with Down syndrome (Behrman et al, 1987). By the age of 6 months the clinical diagnosis of hypothyroidism could be easier. Older children may show severe retardation in growth with manifestation of hypothyroidism and may stand out in stark contrast to age related peers with Down syndrome in school activities.

Other abnormalities may suggest the presence of a thyroid disorder; eg, abnormal electrocardiogram consistent with hypothyroidism, (Murdoch, 1977), presence of a goitre (Ruvalcaba, 1969; Hollingworth, 1974), detection of a pericardial effusion (Werder et al, 1993), dementia (Prasher \& Krishnan, 1993), detection of alopecia areata (duVivier \& Munro, 1975), premature puberty (Maranon et al, 1951).

Several aspects of thyroid disorders in the Down syndrome population have been further investigated. Criscuolo et al (1986) and Sharav et al, (1991) have suggested that in persons with Down syndrome subclinical primary hypothyroidism could be diagnosed by testing the hypothalamic-pituitary-thyroid pathway by detection of an exaggerated and prolonged TSH response to TRH (thyrotrophin releasing hormone).

Other studies have studied the role of trace elements in the aetiology of thyroid dysfunction. In particular alteration of zinc metabolism has been reported in studies of persons with Down syndrome (Napolitano et al, 1990; Licastro et al, 1992; Toledo et al, 1997; Sustrova \& Strbak, 1994) and observed in both hyperthyroid and hypothyroid in non-Down syndrome patients (Dolev et al, 1988). Napolitano et al (1990) and Licastro et al (1992) have suggested that zinc deficiency may be a cause of thyroid disorders in Down syndrome. They found patients with Down syndrome had low zinc levels, and that zinc supplementation improved thyroid function and also reduced the incidence of infectious diseases and improved school attendance. As thyroid disorders are difficult to diagnose in people with Down syndrome there should be a "high index of clinical suspicion". In view of the low cost of screening for thyroid disorders, the potential benefits of treatment, and the lack of a clear correlation between clinical and biochemical indications of thyroid disorders, thyroid function tests should be regularly performed (see management). 


\section{Other conditions possibly associated with Down syndrome and thyroid disorders}

\section{i) Premature puberty}

Premature puberty has been reported in both girls and boys. In girls it can present with breast development, pubic hair, vaginal secretion, menstruation, acceleration of growth and in boys with pubic hair, testis enlargement and height spurt.

Barnes et al (1973) studied the association of early puberty with juvenile hypothyroidism in 54 children with primary hypothyroidism (one patient with Down syndrome); and found that 31 of them had evidence of iso-sexual maturation that was advanced when considered in relation to the "maturational" (bone) age. They concluded that long-standing thyroid failure induces increased TSH secretion, both indirectly (through the action of thyrotropin - releasing hormone) and directly (at the level of the pituitary) and this action on pituitary may induce subsequent premature sexual development.
Several case reports of premature puberty in children with Down syndrome who were also identified to have hypothyroidism have been reported (Table 6). It is reasonable to assume the mechanism behind such a possible association is similar to that described by Barnes et al (1973). Any association is likely not to be a common occurrence but professionals in contact with children with Down syndrome who are diagnosed has having a thyroid disorder should be alert to the possibility of other endocrine disorders.

\section{ii) Diabetes Mellitus}

Diabetes mellitus is a metabolic disorder characterised by high blood sugar levels due usually to insulin deficiency. Common symptoms include large amounts of urine excretion, thirst and weight loss. Case reports of the occurrence of diabetes in persons with Down syndrome with hypo or hyperthyroidism have been reported (Table 6). An association between autoimmune thyroid disease and diabetes mellitus is well recognised and it is likely, for people with Down

Table 6: Reported conditions associated with Down syndrome and thyroid disorders.

\begin{tabular}{|c|c|c|c|c|c|}
\hline CONDITION & THYROID DISORDER & AGE & SEX & AUTHOR (Ref) & YEAR \\
\hline \multirow[t]{9}{*}{ Early Puberty } & Hypothyroidism & 12 & $M$ & Maranon et al & 1951 \\
\hline & & 5 & $\mathrm{~F}$ & Hubble & 1963 \\
\hline & & 13 & $\mathrm{~F}$ & Hayles et al & 1965 \\
\hline & & 8 & $\mathrm{~F}$ & Pabst et al & 1967 \\
\hline & & 9 & $\mathrm{~F}$ & Fliegelman \& Reisman & 1968 \\
\hline & & 9 & $\mathrm{~F}$ & Aarskog & 1969 \\
\hline & & 8 & $\mathrm{~F}$ & Costin et al & 1972 \\
\hline & & 16 & $\mathrm{~F}$ & Tonz \& Trost & 1974 \\
\hline & & 9 & $F$ & Floret et al & 1978 \\
\hline \multirow[t]{7}{*}{ Diabetes Mellitus } & Hypothyroidism & 17 & $M$ & Daniels \& Simon & 1968 \\
\hline & & 1 & $M$ & Litman & 1968 \\
\hline & & 6 & $M$ & Shaheed \& Rosenblood & 1973 \\
\hline & & 5 & $\mathrm{~F}$ & Parkin & 1974 \\
\hline & & 13 & $\mathrm{~F}$ & Ong \& Schneider & 1976 \\
\hline & & 17 & $\mathrm{~F}$ & Radetti et al & 1986 \\
\hline & & 33 & $\mathrm{~F}$ & Stein \& Jewell & 1979 \\
\hline \multirow[t]{4}{*}{ Hyperthyroidism } & & 13 & $\mathrm{~F}$ & Kay \& Esselborn & 1963 \\
\hline & & 13 & $F$ & 11 & " \\
\hline & & 9 & $M$ & Bhowmick \& Grubb & 1997 \\
\hline & & 6 & M & Subrt et al & 1968 \\
\hline \multirow[t]{7}{*}{ Cardiac Disease } & Hypothyroidism & 9 & $F$ & Heydarian et al & 1987 \\
\hline & & 9 & $\mathrm{~F}$ & Werder et al & 1993 \\
\hline & & 12 & $M$ & " & 11 \\
\hline & & $9 \mathrm{~F}$ & $\mathrm{~F}$ & " & " \\
\hline & & 10 & $\mathrm{~F}$ & Feliz de Vargas Pastor et al & 1993 \\
\hline & & $13 / 12$ & $\mathrm{~F}$ & Fargas et al & 1996 \\
\hline & Hyperthyroidism & 15 & $F$ & Takahashi et al & 1979 \\
\hline Seminoma & Hypothyroidism & 6 & $M$ & Matsaniotis et al & 1967 \\
\hline Alopecia & Hypothyroidism & 27 & $M$ & Scotson & 1989 \\
\hline Hypoparathyroidism & Hyperthyroidism & 13 & $M$ & Blumberg \& Ruskin & 1987 \\
\hline Gastrointestinal Anomalies & Hypothyroidism & $<1$ & - & Jaruratanasirkul et al & 1998 \\
\hline Coeliac Disease & Hyperthyroidism & 8 & $\mathrm{~F}$ & Crespo et al & 1996 \\
\hline Dementia & Hypothyroidism & 38 & $\mathrm{~F}$ & Thase & $1982 b$ \\
\hline
\end{tabular}


syndrome, that a generalised autoimmune disorder is the underlying cause. Appropriate management by a specialist diabetic service is required to prevent serious complications.

\section{iii) Dementia (Alzheimer's disease)}

Untreated hypothyroidism resulting in intellectual decline is now recognised to occur in adults with Down syndrome (Thase 1982a, Prasher \& Krishnan, 1993). Appropriate treatment can lead to significant improvement. The commonest form of dementia- Alzheimer's disease- is particularly prevalent in older adults with Down syndrome (Oliver \& Holland, 1986; Prasher \& Krishnan, 1993). Research in the general population has suggested that thyroid disorders may predispose to AD (Heyman et al, 1983; Mortimer, 1990). There is no definite evidence showing that thyroid disorders predisposes to $\mathrm{AD}$ in the Down syndrome population. However, Percy et al (1990) suggested that "subclinical" hypothyroidism may contribute to cognitive deficits in ageing Down syndrome patients and Bhaumik et al (1991) have shown that elevated levels of TSH in a group of patients with Down syndrome inversely correlated with scores of global adaptive abilities. Although further research is required, it is unlikely that thyroid hormone estimation is of any clinical value as a peripheral marker of Alzheimer's disease (Prasher, 1995).

\section{iv) Other conditions}

Several case reports have been published illustrating the occurrence of Down syndrome, thyroid dysfunction (hyperthyroidism or hypothyroidism) and other physical disorders (Table 6). Large scale epidemiological studies are required to fully investigate definite associations but it is possible there is an underlying impairment of autoimmune function leading to multi-systemic dysfunction. From reports to date particular associated conditions are early puberty, diabetes mellitus and cardiac disease. For the general population an association between thyroid dysfunction and depression has been reported but no such association was found for adults with Down syndrome (Prasher \& Hall, 1996).

\section{Immunological aspects}

An association between Down syndrome and immunological disorders, in particular susceptibility to infections, malignancies and autoimmunity, has been highlighted by many researchers (Gershwin et al, 1977; Ugazio et al, 1992). The underlying cause is still to be fully described but is related to $\mathrm{T}$ cell derangement, abnormalities with antibody-mediated immunity and dysfunction of phagocytosis (Wisnewiski et al, 1979; Rabinowe et al, 1989; Ugazio et al, 1992). The susceptibility to autoimmune thyroiditis being further related to as yet unidentified specific genes on chromosome 21 (Nicholson et al, 1994).

The relationship between Down syndrome and autoimmune thyroid disease is irrespective of the underlying karyotype (Robertson et al, 1965) and was first described by Mellon et al (1963). The association has been confirmed by subsequent reports (Table 7). Hashimoto's thyroiditis (lymphocytic thyroiditis), was first described by Roitt et al in 1956, and is also a common condition in the Down syndrome population (Saxena \& Crawford, 1962; Leboeuf \& Bongiovanni, 1964).

Persons with Down syndrome with circulating thyroid autoantibodies may present with hypothyroidism (Baxter et al 1975; Murdoch et al, 1977; Lobo et al, 1980; Dinani \& Carpenter, 1990), hyperthyroidism (Aarskog, 1969; Blumberg \& Ruskin, 1987) or may be euthyroid (Hollingsworth et al, 1974). Further, not all individuals with clinical thyroid disease have auto-antibodies (Cutler et al, 1986). Thyroid auto-antibodies may be either anti-thyroid globulin antibodies (ATAs) or anti-microsomal antibodies (AMAs). There maybe elevated ATAs and AMAs or increased ATAs or AMAs only.

In Pueschel \& Pezzullo's study (1985) of 47 patients (of a total sample of 151) with elevated thyroid antibodies 14 had both elevated ATA and AMA titres, 5 with increased ATA titres and 28 had elevated AMA titres. Vladutiu et al (1984) detected thyroid antibodies in 16 of 42 patients $(38 \%)$ and 9 persons were positive for ATAs. Only 5 patients $(12 \%)$ were positive for both ATAs and AMAs whereas 4 had only ATAs and 7 only AMAs. In the 5 subjects positive for thyroid antibodies no evidence of hypothyroidism was found.

The relationship between certain chromosomal abnormalities (especially Down syndrome and Turner's Syndrome) and thyroid autoimmunity has been reviewed by Bright et al (1982). There are several hypotheses that attempt to describe this association; (i) chromosomal abnormalities may result in secondary autoimmune disease (ii) pre-existing autoantibodies in the mother may predispose to a chromosomal abnormality in the child (iii) both aneuploidy and autoimmune disease may be a result of another (unknown) process. There is little evidence to favour any one of these hypotheses over the others at present, although some studies have shown an 


\begin{tabular}{|c|c|c|c|c|c|}
\hline AUTHOR (Ref) & YEAR & $\begin{array}{l}\text { NO. OF DS } \\
\text { PATIENTS } \\
\text { STUDIED }\end{array}$ & $\begin{array}{l}\text { AGE } \\
\text { (YRS) }\end{array}$ & $\begin{array}{l}\text { PRESENCE } \\
\text { OF THYROID } \\
\text { ANTIBODIES }\end{array}$ & $\begin{array}{l}\text { DS SUBJECTS } \\
\text { RELATIVES/CONTROLS }\end{array}$ \\
\hline Mellon et at & 1963 & 35 & $10-60$ & $20 \%$ & $30 \%$ relatives \\
\hline Burgio & 1965 & 12 & $3 / 12-10$ & $58 \%$ & $50 \%$ mothers \\
\hline Saxena \& Pryles & 1965 & 50 & $1-15$ & $28 \%$ & $7 \%$ normal controls \\
\hline Dallaire et al & 1969 & $86^{*}$ & - & - & $\begin{array}{l}23 \% \text { mothers } \\
10 \% \text { mother controls }\end{array}$ \\
\hline Fialkow & 1970 & 106 & - & $34 \%$ & $\begin{array}{l}6 \% \text { controls. } 12 \% \text { sibs. } \\
3 \% \text { sib controls. } 9 \% \text { fathers. } \\
7 \% \text { father controls. } 30 \% \text { mothers. } \\
14 \% \text { mother controls. }\end{array}$ \\
\hline Vanhalst et al & 1970 & 21 & $1-21$ & $24 \%$ & $\begin{array}{l}28 \% \text { mothers. } \\
13 \% \text { mother controls. } 24 \% \text { sibs. }\end{array}$ \\
\hline Hollingsworth et al & 1974 & 60 & $9-65$ & $85 \%$ & $38 \%$ mental handicap controls. \\
\hline Baxter et al & 1975 & 11 & $44-65$ & $45 \%$ & - \\
\hline Piffanelli et al & 1974 & 73 & $6-22$ & $32 \%$ & - \\
\hline Murdoch et al & 1977 & 82 & $19-65$ & $13 \%$ & - \\
\hline Sare et al & 1978 & 121 & $13-48$ & $33 \%$ & - \\
\hline Korsager et al & 1978 & 24 & $41-60$ & $33 \%$ & - \\
\hline Lobo et al & 1980 & 101 & $5-47$ & $30 \%$ & - \\
\hline Vladitiu & 1984 & 42 & $18-60$ & $38 \%$ & - \\
\hline Ziai et al & 1984 & 62 & $5-16$ & $30 \%$ & - \\
\hline Pueschel \& Puzzullo & 1985 & 151 & $3-21$ & $31 \%$ & - \\
\hline Loudon et al & 1985 & 95 & $9 / 12-19$ & $29 \%$ & $\begin{array}{l}30 \% \text { relatives autoimmune conditions } \\
15 \% \text { thyroid disorder. }\end{array}$ \\
\hline Cutler et al & 1986 & 49 & $4 / 12-3$ & $4 \%$ & \\
\hline \multicolumn{6}{|l|}{-} \\
\hline Kinnell et al & 1987 & 111 & $22-72$ & $29 \%$ & $9 \%$ controls \\
\hline Mani & 1988 & 48 & $24-67$ & $19 \%$ & - \\
\hline Friedman et al & 1989 & 66 & $2-59$ & $39 \%$ & - \\
\hline Dinani \& Carpenter & 1990 & 61 & $20-67$ & $34 \%$ & - \\
\hline Zori et al & 1990 & 61 & $5 / 12-48$ & $28 \%$ & - \\
\hline Pozzan et al & 1990 & 108 & $3 / 12-38$ & $12 \%$ & $8 \%$ parents \\
\hline Abdullah et al & 1994 & 50 & $7 / 12-9$ & $14 \%$ & $0 \%$ controls \\
\hline Invarsson et al & 1997 & 70 & $1-19$ & $39 \%$ & - \\
\hline
\end{tabular}

* Study of mothers of patients with Down syndrome.

increase in frequency of thyroid autoantibodies in mothers of patients with Down syndrome (Mellon et al, 1963; Doniach et al, 1965; Fialkow, 1970; Vanhaelst et al, 1970).

Hepatitis B and autoimmune thyroiditis occur frequently in the Down syndrome population. Several studies (Fialkow et al, 1971; Ugazio et al, 1977; Sutnick et al, 1972; Ferris et al, 1972; Hollingsworth et al, 1974), have demonstrated an increase in the presence of the Hepatitis B surface antigen (HBsAg; Australia antigen) in the Down syndrome population, compared to controls. Hollingsworth et al (1974) found HBsAg positive in 16 of $60(27 \%)$ of their Down syndrome patients but in none of their learning disabled controls. Thyroid antibodies were present in 5 of 6 pateints with Down syndrome and in only one of 60 controls.

May and Kawanishi (1996) investigated a possible association between HBsAg and thyroid autoimmunity in 57 adults with Down syndrome. They found the frequency of autoimmune thyroiditis in patients with Down syndrome who were also carriers of hepatitis B surface antigen ( $\mathrm{HBsAg}$ ) was threefold higher than the frequency of thyroid disease patients with Down syndrome who were not carriers of HBsAg (65\% v 23\%). The significance of these findings is unclear but chronic exposure to HBsAg may lead to autoimmune thyroid disease in persons with Down syndrome.

\section{Genetic aspects}

Hereditary factors, as in the general population (Doniach et al, 1965), appear to play a part in the aetiology of thyroid disorders in the Down syndrome population. Several studies have shown significantly higher thyroid disorders and thyroid autoimmune disease in the parents or siblings of affected individuals (Table 7).

The precise role of hereditary factors remain uncertain but several hypotheses have been previously proposed. One fascinating hypothesis was by Fialkow in 1966 when he hypothesised that thyroid disorders in the mothers of children 
with Down syndrome ante-dates the birth of a child with Down syndrome and predispose to gamete/chromosome abnormality and thereby to a child with Down syndrome. Although support for this controversial hypothesis was given by other investigators (Engel, 1967; Dallaire et al, 1969; Flannery et al, 1984, 1986) recent, more methodologically improved studies, found little evidence of support. Torfs et al (1990) measured levels of thyroid antibodies in serum samples drawn during early pregnancy from 101 gravidas who delivered a child with a trisomy, from 11 gravidas who had had a trisomic child in a previous pregnancy, and from 44 fathers was investigated along with serum from matched controls. Overall, there was no association between the presence of thyroid antibodies in a mother and a trisomy birth. Case fathers, as compared with control fathers, did not have a higher prevalence of thyroid antibodies. Gustafsson et al (1995) measured the incidences of thyroglobulin and thyroid peroxidase antibodies in 29 mothers giving birth to children with trisomy 21 and in 87 control mothers. Samples collected at delivery. There was no statistical difference regarding the proportion of thyroid antibodies in the two groups. The authors concluded that the presence of thyroid antibodies in the serum of a pregnant woman has no prognostic value for the birth of an infant with Down syndrome.

Most cases of trisomy 21 are due to maternal non-disjunction at first meiosis and the role of maternal age effect is unexplained. The proposition that lack of chiasma formation at a critical stage of chromosome separation could lead to Down syndrome (Hulten, 1990) suggests the possibility of maternal age-related disease having a mechanical effect in the process of disjunction. The effect of varying concentrations of thyroxine on the process of gamete formation needs further animal and tissue culture studies and could still provide considerable evidence for Fialkow's hypothesis.

\section{Management of thyroid disorders}

With the advent of chromosomal analysis and the ready availability of thyroid function tests, inappropriate diagnosis and treatment of thyroid disorders in persons with Down syndrome should no longer occur. Results of thyroid function tests may need to be interpreted with caution especially in individuals who are already susceptible to acute illnesses and are often taking one or more drugs. Hormone levels may fluctuate and abnormalities be transient. Monitoring may in many cases be all that is required.
Once the diagnosis of a thyroid disorder has been made, depending on its severity and type (hypothyroidism or hyperthyroidism, presence or absence of thyroid antibodies) management is generally similar to that in the general population (Rae et al, 1993).

\section{i) Hypothyroidism}

Definite hypothyroidism is treated with thyroxine replacement and usually needed for life. Improvement is seen in physical symptoms (Korsager \& Andersen, 1979), regrowth of hair (Scotson, 1989), improvement in cognitive functioning (Thase, 1982b; Prasher \& Krishnan, 1993) and social functioning (Prasher \& Krishnan, 1993). The clinical benefit of zinc supplementation in the management of hypothyroidism in individuals with Down syndrome requires further investigation (Napolitano et al, 1990; Sustrova \& Strbak, 1994).

\section{ii) Hyperthyroidism}

Hyperthyroidism is treated with measures to reduce thyroxine activity, Medically with carbimazole, propylthiouracil or radioactive iodine (Diggle \& Weetch, 1958; Nibhanupudy et al, 1986; Bhomwmick and Grubb, 1997).

Surgical intervention involves partial thyroidectomy but this is rarely undertaken in patients with Down syndrome. The principal complication of these forms of treatment for hyperthyroidism is resultant hypothyroidism (Bhomwmick \& Grubb, 1997).

\section{iii) Subclinical Hypothyroidism}

Controversy remains regarding the management of subclinical hypothyroidism. Recent

longitudinal studies of thyroid dysfunction in the Down syndrome population (Rubello et al, 1995; Prasher, 1996; Selikowitz, 1993) suggest that subclinical hypothyroidism is a common transient condition in people with Down syndrome.

Evidence would suggest it can occur with or without presence of thyroid autoimmunity. Selikowitz (1993) in a 5 year longitudinal study of 101 children found 8 children developed subclinical hypothyroidism which in half resolved spontaneously at the end of the study period.

Rubello et al (1995) found that in the presence of thyroid autoimmunity, a significant number of individuals with Down syndrome and with subclinical hypothyroidism can develop definite hypothyroidism or hyperthyroidism. In individuals with absence of thyroid autoimmunity spontaneous normalization of TSH levels can occur. 
Appreciable benefit following treatment of subclinical hypothyroidism with thyroid hormone supplementation remains in doubt (Tirosh et al, 1989). These researchers failed to show any efficacy of short-term thyroid hormone therapy for this population as assessed in a double-blind cross-over drug placebo trial.

At present regular frequent monitoring of thyroid status is recommended for individuals with asymptomatic subclinical hypothyroidism but a trial period of thyroxine hormone therapy should be considered for symptomatic cases or those who have positive thyroid peroxidase antibodies.

\section{iv) Screening}

As clinical detection of a thyroid disorders (especially hypothyroidism) in patients with Down syndrome remains difficult (Mani, 1988; Prasher, 1995), regular thyroid function screening should be performed in all age groups of persons with Down syndrome.

Due to the general absence of incidence and long-term follow-up studies of thyroid disorders in the Down syndrome population the following recommendations are made for screening:-

i) Normal thyroid status-repeat tests every two years

ii) Definite hypothyroidism-immediate thyroxine replacement therapy

iii) Subclinical hypothyroidism-repeat tests every year

iv) Definite hyperthyroidism-refer for medical opinion

v) Previous treatment-monitor yearly basis

Whether parents and siblings of a child with Down syndrome should also be assessed for thyroid disorders remains speculative. As the Down syndrome population continues to grow greater awareness amongst carers and professionals is required. With the advent of community care the importance of early detection of thyroid disorders needs to be particularly understood by general practitioners (Cumella et al 1992).

\section{Conclusions}

The association between Down syndrome and thyroid disorders is of both academic and clinical importance. There is a high prevalence of thyroid disorders; hypothyroidism commoner than hyperthyroidism, both congenital and acquired, more frequent in females than males and increasing with age. A "high index of suspicion" is required as the diagnosis of thyroid disorders in people with Down syndrome is difficult.
Presentation may be atypical or may be associated with other medical conditions (premature puberty, diabetes mellitus, dementia). A number of immunological and genetic aspects still require further investigation. Management of thyroid disorders is similar to that in the general population but a greater emphasise on screening is required.

\section{Correspondence}

V. P. Prasher, Department of Psychiatry, University of Birmingham, Queen Elizabeth Psychiatric Hospital, Mindelsohn Way,

Edgbaston, Birmingham, England. B15 2QZ. (Tel: 0121627 2831, Fax: 0121627 2832, E-mail: vprasher@compuserve.com)

\section{Acknowledgements}

I would like to thank Professor J.A Corbett, Professor of Developmental Psychiatry, Dr D.J. Clarke, Senior Lecturer in Developmental Psychiatry and V.H.R Krishnan, Consultant Psychiatrist in Learning Disabilities with their help in writing earlier drafts of this manuscript. 


\section{References}

Aarskog, D. (1969). Autoimmune thyroid disease in children with mongolism. Archives of Diseases of Childhood, 44, 454-460.

Abdullah, M.A., Salman, H., Al-Habib, S., Ghareeb, A. \& Abanamy, A. (1994). Antithyroid antibodies and thyroid dysfunction in Saudi children with Down syndrome. Annals of Saudi Medicine, 14, 283-285.

Abrahamsen, A.M. (1961). Thyrotoxicosis in two adult mongols. Acta Endocrinologica, 37, 135-137.

Alberman, E. (1978). Main causes of major mental handicap: prevalence and epidemiology. In Major Mental Handicap: Methods and cost of prevention (CIBA Foundation Symposium 59), 3-16.

Ansari, A.H. \& Schneeberg, N.G. (1967). Thyrotoxicosis in a mongol. Canadian Medical Association Journal, 96, 425-427.

Azizi, F., Chandler, H., Bozorgzadeh, H. \& Braverman, L.E. (1974). The occurrence of hyperthyroidism in patients with Down's syndrome. Hopkins Medical Journal, 134, 303-306.

Barnes, N.D., Hayles, A.B. \& Ryan, J.R. (1973). Sexual maturation in juvenile hypothyroidism. Mayo Clinic Proceedings, 48, 849-856.

Baxter, R.G., Martin, F.I.R., Larkins, R.G., Heyma, P., Myles, K. \& Ryan, L. (1975). Down syndrome and thyroid function in adults. Lancet ii, 794-796.

Behrman, R.E., Vaughan, V.C. \& Nelson, W.E. (1987). Disorders of thyroid gland. In R.E. Behrman, V.C. Vaughan, and W.E. Nelson (Eds.). Nelson Text Book of Paediatrics. 13th edition, London: W.B. Saunders Company.

Benda, C.E. (1946). Mongolism and cretinism. New York: Grune \& Stratton.

Benda, C.E. (1949). Mongolism and cretinism. 2nd Ed, New York: Grune \& Stratton.

Bhaumik, S., Collacott, R.A., Garrick, P. \& Mitchell, C. (1991). Effect of thyroid stimulating hormone on adaptive behaviour in Down syndrome, Journal of Mental Deficiency Research, 35, 512520.

Bhomwmick, S.K. \& Grubb, P.H. (1997). Management of multiple-antibody-mediated hyperthyroidism in children with Down's syndrome. Southern Medical Journal, 90, 312-315.

Blumberg, D. \& Ruskin, T. (1987). Down's syndrome, autoimmune hyperthyroidism, and hypoparathyroidism: a unique triad. American Journal of Diseases of Children, 141, 1149.

Bournville. (1903). L'idiotie Mongolienne. Progress Medecine, 3, 117.

Bright, G.M., Blizzard, R.M., Kaiser, D.L. \& Clarke, W.L. (1982). Organ-specific autoantibodies in children with common endocrine diseases. Journal of Paediatrics, 100, 8-14.

Burgio, G.R., Severi, F., Rossoni, R. \& Vaccaro, R. (1965). Mongolism and thyroid autoimmunity. Lancet, i, 166-167.

Coleman, M. \& Abbassi, V. (1984). Down's syndrome and hypothyroidism; coincidence or consequence? Lancet, i, 569.

Costin, G., Kershnar, A.K., Kognt, M.D. \& Turkington, R.W. (1972). Prolactin activity in juvenile hypothyroidism and precocious puberty. Paediatrics, 50, 881- 889.

Crespo Cuadrado, E., Azcona San Julian, C., Castro Paz, L., Diaz-Tejeiro, P., Rodriguez Javier, S. \& Sierrasesumaga Ariznabarreta, L. (1996). Autoimmune hypothyroidism and celiac disease in a girl with Down's syndrome. Revista Espanola de Pediatria, 52, 485-488.

Criscuolo, T., Perrone, L., Sinisi, A.A., Bellastell, A. \& Faggiano, M. (1986). Subclinical hypothyroidism in children with Down's syndrome. Minerva Endocrinologica, 11, 169-171.

Cumella, S. Corbett, J.A. Clarke, D.J. \& Smith, B. (1992) Primary health care for people with a mental handicap. Mental Handicap, 20, 123-125.

Cutler, A.T., Benezra-Obeiter, M.D. \& Brink, S.J. (1986). Thyroid function in young children with Down syndrome. American Journal of Diseases of Children, 140, 479-483. 
Dallaire, L., Kingsmill-Flynn, D. \& Leboeuf, G. (1969). Autoimmunity and chromosomal aberrations: serological studies in mothers of children with Down's syndrome. Canadian Medical Association Journal, 100, 1-4.

Daniels, D.G. \& Simon, J.L. (1968). Down's syndrome, hypothyroidism, and diabetes mellitus. Journal of Paediatrics, 72, 697-699.

Diggle, J.H. \& Weetch, R.S. (1958). Thyrotoxicosis in a mongol. Proceedings of the Royal Society of Medicine 51, 293-294.

Dinani, S. \& Carpenter, S. (1990). Down's syndrome and thyroid disorder. Journal of Mental Deficiency Research, 34, 187-193.

Dolev, E., Deuster, P.A., Soloman, B., Trostman, U.H., Wartopsky, L. \& Burman, K.D. (1988). Alteration in zinc and magnesium metabolism in thyroid disease. Metabolism, 37, 61-67.

Doniach, D., Nilsson, L.H. \& Roitt, I.M. (1965). Autoimmune thyroiditis in children and adolescents: immunological and parent study. Acta Paediatrica Scandinavica, 54, 260-274.

Dupuy, F.I. \& Madrigal, R.G. (1957). Hipertiroidismo en un mongol. Archivos Del Hospital Universitario, 9, 389- 395.

Dura, T., Juste, M., Herranz, Y., Gonzalez, R., De Dios, J.G. \& Moya, M. (1995). Autoimmune hypothyroidism in a child with Down's syndrome. Acta Pediatrica Espanola, 53, 51 1-514.

Du Vivier, A. \& Munro, D.D. (1975). Alopecia areata, autoimmunity, and Down's syndrome. British Medical Journal, 1, 191-192.

Esen, F.M. \& Mautner, H. (1957). Hypo- and Hyperthyroidism in mongolism. Archives of Paediatrics, 74, $291-302$.

Fargas, A., Martinez, J., Dominguez, P., Albert, D.C., Yeste, D. \& Toran, N. (1996). Thirteen month old girl with Down syndrome, pericardial effusion and hypothyroidism. Pediatria Catalana, 56, 3942.

Feliz De Vargas Pastor, J., Garcia Jimenez, I., Garcia Lopez, P., Sanchez Miramon, F., Bone Calvo, J. \& Baldellou Vazquez, A. (1993). Diagnosis of autoimmune thyroiditis through the study of pericardial effusion of a girl with Down's syndrome. Anales Espanoles de Pediatria, 38, 68-70.

Ferris, A.A., Pitt, D.B., Gust, I.D. \& Kaldor, J. (1972). Australia antigen and Down's syndrome. Lancet i, 46.

Fialkow, P.J., Hecht, F., Uchida, I.A. \& Motulsky, A.G. (1965). Increased frequency of thyroid autoantibodies in mothers of patients with Down's syndrome. Lancet ii, 868-870.

Fialkow, P.J. (1970). Thyroid autoimmunity and Down's syndrome. Annals of New York Academy of Sciences, 171, 500-511.

Fialkow, P.J., Thuline, H.C., Hecht, F. \& Bryant, J. (1971). Familial predisposition to thyroid disease in Down's syndrome: Controlled immunoclinical studies. American Society of Human Genetics, 23, 67-86.

Fialkow, P., Blumberg, B., London, W., Sutnick, A. \& Thuline, H. (1971). Thyroid antibodies and Australian antigen in Down's syndrome. Journal of Mental Deficiency Research, 15, 177-180.

Fliegelman, M.T. \& Reisman, L.E. (1968). Double trouble - Down's syndrome and hypothyroidism. Cutis, 4, 1241- 1245.

Floret, D., Thomas, A., Claustrat, B. \& Monnet, P. (1978). Trisomie 21, Myxodeme par thyroidite avec puberte precoce - par entrainement Etude de la secretion des gonadostimulines et de la prolactine. Pediatrie, 18, 189-200.

Fort, P., Lifshitz, F., Bellisario, R., Davis, J., Lanes, R., Pugliese, M., Richman, R., Post, E.M. \& David, R. (1984). Abnormalities of thyroid function in infants with Down syndrome. Journal of Paediatrics, 104, 545-549.

Friedman, D.L., Kastner, T., Pond, W.S. \& O'Brien, D.R. (1989). Thyroid dysfunction in individuals with Down syndrome. Archives of Internal Medicine, 149, 1990-1993.

Gershwin, M.E., Crinella, F.M., Castles, J.J. \& Trent, J.K.T. (1977). Immunologic characteristics of Down's syndrome. Journal of Mental Deficiency Research, 21, 237-249. 
Gilchrist, L. (1946). Thyrotoxicosis in a mongol. British Medical Journal, 1, 237-238.

Gillberg, I.C., Gillberg, C., \& Kopp, S. (1992). Hypothyroidism and autistic spectrum disorders. Journal of Child Psychology and Psychiatry, 33, 531-542.

Gordon, M.B. (1930). Morphological changes in the endocrine glands in mongolian idiocy with report of two cases. Endocrinology, 14, 1-5.

Gustafsson, J., Anneren, G., Ericsson, U.B., Svanberg, L., Ivarsson, S.A. (1995). Thyroid antibodies are not a risk factor for pregnancies with Down syndrome. Prenatal Diagnosis, 15, 451-454.

Harris, F. \& Koutsoulieris, E. (1967). Hypothyroidism due to autoimmune thyroiditis in a young child with Down's syndrome. Archives of Diseases of Childhood, 42, 449-452.

Hayles, A.B., Hinrich, W.L. \& Tauxe, W.N. (1965). Thyroid disease among children with Down's syndrome (mongolism). Paediatrics, 36, 608-614.

Hestnes, A., Stovner, L.J., Husoy, O., Folling, I., Fougner, K.J. \& Sjaastad, O. (1991). Hormonal and biochemical disturbances in Down's syndrome. Journal of Mental Deficiency Research, 35, 179-193.

Heydarian, M., Kelly, J.P. \& Young, L.W. (1987). Radiological case of the month. American Journal of Diseases of Children, 141, 641.

Heyman, A., Wilkinson, W.E., Hurwitz, B.J., Schmechel, D., Sigmon, A.H., Weinberg, T., Helms, M.J. \& Swift, M. (1983). Alzheimer's disease: Genetic aspects and associated clinical disorders. Annals of Neurology, 14, 507- 515.

Hill, B. (1908). Mongolianism and it's pathology. Quarterly Journal of Medicine, 2, 49-69.

Hillman, J.C. (1969). Thyroid-stimulating hormone and thyroxine levels in the plasma of patients with Down's syndrome. Journal of Mental Deficiency Research, 13, 191-196.

Hollingsworth, D.R., Mckean, H.E. \& Roeckel, I. (1974). Goitre, immunological observations, and thyroid function tests in Down syndrome. American Journal of Diseases of Children, 127, 524-527.

Hubble, D. (1963). Precocious menstruation in a mongoloid child with hypothyroidism-hormonal overlap. Archives of Diseases of Childhood, 23,1302-1305.

Hughes, V.C., Cameron, J. \& Goonetilleke, A.S.R. (1982). The prevalence of thyroid dysfunction in mentally handicapped in-patients. Journal of Mental Deficiency Research, 26, 115-120.

Hulten, M.A. (1990). The origin of aneuploidy: Bivalent instability and the maternal age effect in trisomy 21 Down syndrome. American Journal of Genetics Supplement, 7, 160-161.

Iughetti, L., Cassaro, F., De Fanti, A., Vanelli, M. \& Ottaviani A. (1993). Endocrinopatie autoimmuni e sindrome di Down: descrizione di un caso. Pediatria Medica E Chirurgica, 15, 207-208.

Ivarsson, S.A., Ericsson, U.B., Gustafsson, J., Forslund, M., Vegfors, P. \& Anneren, G. (1997). The impact of thyroid autoimmunity in children and adolescents with Down syndrome. Acta Paediatrica, 86, 1065-1067.

Jaruratanasirikul, S., Patarakijbanich N. \& Patanapisarnsak, C. (1998). The association of congenital hypothyroidism and congenital gastrointestinal anomalities in Down's syndrome infants. Journal of Pediatric Endocrinology, 11, 241-246.

Johnson, J.E. \& Cook, A.R. (1962). Hyperthyroidism in patients with mongolism. Journal of Clinical Endocrinology, 22, 665-668.

Kay, C.J. \& Esselborn, V.M. (1963). Hyperthyroidism and mongolism. American Journal of Diseases of Children, 106, 411-414.

Kennedy, R.L., Jones, T.H. \& Cuckle, H.S. (1992). Down's syndrome and the thyroid. Clinical Endocrinology, 37, 471-476.

King, S.L., Ladda, R.L. \& Kulin, H.E. (1978). Hypothyroidism in an infant with Down's syndrome. American Journal of Diseases of Children, 132, 96-97.

Kinnell, H.G., Gibbs, N., Teale, J.D. \& Smith, J. (1987). Thyroid dysfunction in institutionalised Down's syndrome adults. Psychological Medicine, 17, 387- 392. 
Korsager, S., Chatham, E.M. \& Kristensen, P.O. (1978). Thyroid function tests in adults with Down's syndrome. Acta Endocrinologica, 88, 48-54.

Korsager, S. \& Andersen, M. (1979). Thyroid replacement therapy in Down's syndrome with hypothyroidism. Journal of Mental Deficiency Research, 23, 105-110.

Langdon-Down, J. (1866). Oberservations on an ethnic classification of idiots. London Hospital Reports 3, 259-262.

Leboeuf, G. \& Bongiovanni, A.M. (1964). Thyroiditis in childhood. Advances in Paediatrics, 13, 183212.

Lejeune, L., Gautier, M. \& Turpin, R. (1959). Les chromosomes humainsen culture de tisshu. Comptes Rendus de l'Academie des Sciences, 248, 602-603.

Licastro, F., Mocchegiani, E., Zannotti, M., Arena, G., Masi, M. \& Fabris, N. (1992). Zinc affects the metabolism of thyroid hormones in children with Down's syndrome: Normalization of thyroid stimulating hormone and of reversal triiodothyronine plasmic levels by dietary zinc supplementation. International Journal of Neuroscience, 65, 259-268.

Litman, N.N. (1968). Down's syndrome, hypothyroidism, and diabetes mellitus. Journal of Paediatrics, 73, 798.

Lobo, E.H., Khan, M. \& Tew, J. (1980). Community study of hypothyroidism in Down's syndrome. British Medical Journal, 280, 1253.

Loudon, M.M., Day, R.E. \& Duke, E.M. (1985). Thyroid dysfunction in Down's syndrome. Archives of Disease in Childhood, 60, 1149-1151.

Lunde, P.K.M. (1959). Samtidig forekomst av mongolisme og hypothyreose. Tidsskrift for Den Norske Laegeforening, 79, 394-396.

Mani, C. (1988). Hypothyroidism in Down's syndrome. British Journal of Psychiatry, 153, 102-104.

Maranon, G., Martinez Diaz. \& Gochi Mendizabal, J.M. (1951). Mongolismeet macrogenitosomie. Annales D'endocrinologie, 12, 41-48.

Matsaniotis, N., Karpouzas, J. \& Economou-Mavrou, C. (1967). Hypothyroidism and seminoma in association with Down's syndrome. Journal of Paediatrics, 70, 810-812.

May, P. \& Kawanishi, H. (1996). Chronic hepatitis B infection and autoimmune thyroiditis in Down syndrome. Journal of Clinical Gastroenterology, 23, 181-184.

McGirr, E.M. \& Murray, I.P.C. (1956). Thyrotoxicosis in a mongol. Journal of Clinical Endocrinology, 16,160- 163.

Mellon, J.P., Pay, B.Y. \& Green, D.M. (1963). Mongolism and thyroid autoantibodies. Journal of Mental Deficiency Research, 7, 31-36.

Mortimer, J.A. (1990). Genetic and environmental risk factors for Alzheimer disease; Key questions and new approaches. In H. Altman (Ed.) Alzheimer Disease and Dementia. Problems, Prospects, and Perspectives. New York: Plenum Press.

Morton, D.A. \& Jenkins, M.E. (1978). Down's syndrome and thyroid dysfunction. Journal of the National Medical Association, 70, 27-29.

Murdoch, J.C., Ratcliffe, W.A., Mclarty, D.G., Rodger, J.C. \& Ratcliffe, J.G. (1977). Thyroid function in adults with Down's syndrome. Journal of Clinical Endocrinology, 44, 453-452.

Myers, C.R. (1938). An application of the control group method to the problem of the etiology of mongolism. Proceedings American Association Mental Deficiency, 62, 142.

Napolitano, G., Palka, G., Lio, S., Bucci, I., De Remigis, P., Stuppia, L. \& Monaco, F. (1990). Is zinc deficiency a cause of subclinical hypothyroidism in Down syndrome? Annales De Genetique, 33, 9-15.

Nibhanupudy, J.R., Streeter, O.E., King, G.C., Mahan, J., Talley,G., Lander, C. \& Ashayeri, E. (1986). Treatment of a Down's syndrome patient for hyperthyroidism with radioactive iodine. Journal of the National Medical Association, 78, 139-143.

Nicholson, L.B., Wong, F.S., Ewins, D.L., Butler, J., Holland, A., Demaine, A.G., McGregor, A.M. (1994). Susceptibility to autoimmune thyroiditis in Down's syndrome is associated with the major 
histocompatibility class II DQA 0301 allele. Clinical Endocrinology, 41, 381-383.

Nickey, L.N. (1960). Thyrotoxicosis in a mongol child. American Journal of Diseases of Children, 99, 680-163.

Ong, E.A. \& Schneider, G. (1976). Down syndrome, hypothyroidism, and diabetes mellitus. American Journal of Diseases of Children, 130, 335-336.

Oliver, C. \& Holland, A.J. (1986). Down's syndrome and Alzheimer's disease: a review. Psychological Medicine, 16, 307-322.

Pabst, H.F., Pueschel, S. \& Hillman, D.A. (1967). Etiologic inter relationship in Down's syndrome, hypothyroidism, and precocious sexual development. Paediatrics, 40, 590-595.

Parkin, J.M. (1974). Down's syndrome, hypothyroidism and diabetes mellitus. British Medical Journal, 2, 384.

Parle, J.V., Franklyn, J.A., Cross, K.W., Jones, S.C., \& Sheppard, M.C. (1991). Prevalence and followup of abnormal thyrotrophin (TSH) concentrations in the elderly in the United Kingdom. Clinical Endocrinology, 34, 77-83.

Pearse, J.J., Reiss, M. \& Suwalski, R.T. (1963). Thyroid function in patients with mongolism. Journal of Endocrinology, 23, 311-312.

Peeters, M.A., \& Lejeune, J. (1994). Elevated TSH levels in young children with Down syndrome: Beneficial effects of supplemental folic acid. Pediatric Reviews \& Communications, 8, 97-103.

Pennacchietti, M. (1935). Contributo anatomo-pathologico allostudio della idiozia mongoloide. Endocrinologia e Patologia Costituzionale, 10, 148-164.

Percy, M.E., Dalton, A.J., Markovic, D., Crapper McLachlan, D.R., Gera, E., Hummel, J.T., Rusk, A.C.M., Somerville, M.J., Andrews, D.F. \& Walfish, P.G. (1990). Autoimmune thyroiditis associated with mild "subclinical" hypothyroidism in adults with Down syndrome: A comparison of patients with and without manifestations of Alzheimer disease. American Journal of Medical Genetics, 36, 148-154.

Piffanelli, A., Dallapiccola, B., Masala, C., Grandonico, F. \& Brocchi, A. (1974). Studio della funzionalita tiroidea nellasindrome di Down. Progresso Medico (Roma), 30,130-138.

Pozzan, G.B., Rigon, F., Girelli, M.E., Rubello, D., Busnardo, B., Baccichetti, C. (1990). Thyroid dysfunction in patients with Down syndrome: Preliminary results from non-institutionalised patients in the Veneto region. American Journal of Medical Genetics Supplement, 7, 57-58.

Prasher, V.P. (1994). Prevalence of thyroid dysfunction and autoimmunity in adults with Down syndrome. Down Syndrome Research and Practice. 2, (2), 67-70.

Prasher, V.P \& Krishnan, V.H.R. (1992). Hypothyroidism presenting as dementia in a person with Down syndrome. Mental Handicap, 21, 147-149.

Prasher. V.P. \& Krishnan, V.H.R. (1993). Age of onset and duration of dementia in people with Down syndrome. A study of 98 reported cases. International Journal of Geriatric Psychiatry, 8, 915-922.

Prasher, V.P. (1995). Age-specified prevalence, thyroid dysfunction and depressive symptomatology in adults with Down syndrome. International Journal of Geriatric Psychiatry, 10, 25-31.

Prasher, V.P. (1995). Reliability of diagnosing clinical hypothyroidism in adults with Down syndrome. Australia \& New Zealand Journal of Developmental Disabilities, 20, 223-233.

Prasher, V.P. \& Hall, W. (1996). Short-term prognosis of depression in adults with Down's syndrome: Association with thyroid status and effects on adaptive behaviour. Journal of Intellectual Disability Research, 40, 32-38.

Prasher, V.P. (1996). Longitudinal screening of thyroid dysfunction in adults with Down's syndrome. Psychiatric Bulletin, 20, 307.

Pueschel, S.M. \& Pezzullo, J.C. (1985). Thyroid dysfunction in Down syndrome. American Journal of Diseases of Children, 139, 636-639.

Pueschel, S.M., Jackson, I.M.D., Giesswein, P., Dean, M.K. \& Pezzullo, J.C. (1991). Thyroid function in Down syndrome. Research in Developmental Disabilities, 12, 287-296. 
Quinn, M.W. (1980). Down's syndrome and hypothyroidism. Irish Journal of Medical Science, 1, 1922.

Rabinowe, S.L., Rubin, L., George, K.L., Adri, M.N.S. \& Eisenbarth, G.S. (1989). Trisomy 21 (Down's syndrome): autoimmunity, aging, and monoclonal antibody-defined T- cell abnormalities. Journal of Autoimmunity, 2, 25-30.

Radetti, G., Drei, F., Betterle, C. \& Mengardoa, G. (1986). Down's syndrome, hypothyroidism and insulin dependent diabetes mellitus. Helvetica Paediatrica Acta, 41, 377-380.

Rae, P., Farrar, J., Beckett, G. \& Toft, A. (1993). Assessment of thyroid status in elderly people. British Medical Journal, 307, 177-180.

Robertson, J., Mellon, J.P. \& Stewart, J.S.S. (1965). Down's syndrome with unusual karyotype and thyroid autoantibodies. Journal of Mental Deficiency Research, 9, 157-163.

Roitt, I.M., Doniach, D., Campbell, P.N. \& Hudson, R.V. (1956). Autoantibodies in Hashimoto's disease (lymph- adenoid goitre). Lancet 2, 820-821.

Rooney, S. \& Walsh, E. (1997). Prevalence of abnormal thyroid function tests in a Down's syndrome population. Irish Journal of Medical Science, 166, 80-82.

Rubello, D., Pozzan, G.B., Casara, D., Girelli, M.E., Boccato, S., Rigon, F., Baccichetti, C., Piccolo, M., Betterie, C. \& Busnardo, B. (1995). Natural course of subclinical hypothyroidism in Down's syndrome: Prospective study results and therapeutic considerations. Journal of Endocrinological Investigation, 18, 35-40.

Ruvalcaba, R.H., Ferrier, P.E. \& Thuline, H.C. (1969). Incidence of goitre in patients with Down's syndrome. American Journal of Diseases of Children, 118, 451-453.

Samuel, A.M., Krishna Murthy, D.S., Kadival, G.V., Patel, Z.M., Mehta, M.N., Ganatra, R.D. \& Ambani, L.M. (1981). Thyroid function studies in young Down's syndrome. Indian Journal of Medical Research, 73, 223-227.

Sare, Z., Ruvalcaba, R.H.A. \& Kelley, V.C. (1978). Prevalence of thyroid disorder in Down syndrome. Clinical Genetics, 14, 154-158.

Saxena, K.M. \& Crawford, J.D. (1962). Juvenile lymphocytic thyroiditis. Paediatrics, 30, 917-926.

Saxena, K.M. \& Pryles, C.V. (1965). Thyroid function in mongolism. Journal of Paediatrics, 67, 363370.

Schindler, A.M. (1989). Hypothyroidism in a child with Down syndrome. Hospital Practice (Office Ed) 24, 227- 232.

Scotson, J. (1989). A patient with Down's syndrome, mild hypothyroidism and alopecia. Practitioner, 233,121 .

Seguin, E. (1866). Idiocy and its treatment by physiological methods. New York.

Selikowitz, M. (1993). A five-year longitudinal study of thyroid function in children with Down syndrome. Developmental Medicine \& Child Neurology, 35, 396-401.

Shaheed, W.A. \& Rosenbloom, L. (1973). Down's syndrome with diabetes mellitus and hypothyroidism. Archives of Diseases of Childhood, 48, 917-918.

Sharav, T., Collins, R.M. \& Baab, P.J. (1988). Growth studies in infants and children with Down's syndrome and elevated levels of thyrotropin. American Journal of Diseases of Children, 142, 13021306.

Sharav, T., Landau, H., Zadik, Z. \& Einarson, T.R. (1991). Age-related patterns of thyroid-stimulating hormone response to thyrotropin-releasing hormone stimulation in Down syndrome. American Journal of Diseases in Children, 145, 172-175.

Smith, T.T. (1896). A peculiarity in the shape of the hand in idiots of the "mongol" type. Paediatrics, 2, 315-320.

Shuttleworth, G.E., (1909). Mongolism imbecility. British Medical Journal, 2, 661-665. 
Stein, G. R. \& Jewell, R.C. (1979). Down's syndrome, hypothyroidism and diabetes mellitus in an adult. Medical Journal of Australia, 2, 9-10.

Subrt, I., Blehora, B. \& Kucera, J. (1968). Aberrant chromosome 13-15 in a patient with Down's syndrome, diabetes mellitus and hyperthyroidism and his father. Acta Genetica et Statistica Medica, $18,38$.

Suresh, T. \& Robertson, P. (1993). Thyroid dysfunction in adults with Down's syndrome. Psychiatric Bulletin, 17, 477-478.

Sustrova, M. \& Strbak, V. (1994). Thyroid function and plasma immunoglobulins in subjects with Down's syndrome (DS) during ontogenesis and zinc therapy. Journal of Endocrinological Investigation, 17, 385-390.

Sutnick, A.I., London, W.T., Blumberg, B.S. \& Gerstley, J.S. (1972). Persistent anicteric hepatitis with Australia antigen in patients with Down syndrome. American Journal of Clinical Pathology, 57, 2-12.

Takahashi, H., Bordy, M.D., Sharma, V. \& Grunt, J.A. (1979). Hyperthyroidism in patients with Down's syndrome. Clinical Paediatrics, 18, 273-275.

Talbot, N.B., Sobel, E.H., McArthur, J.W. \& Crawford, J.D. (1952). Functional endocrinology from birth through adolescence. Harvard University Press: Cambridge, Mass.

Tambyah, P.A. \& Cheah, J.S. (1993). Hyperthyroidism and Down syndrome. Annals Academy of Medicine. 22, (4), 603-605.

Thase, M.E. (1982a). Longevity and mortality in Down's syndrome. Journal of Mental Deficiency Research, 26,177-192.

Thase, M.E. (1982b). Reversible dementia in Down's syndrome. Journal of Mental Deficiency Research, 26, 111-113.

Thorpe-Beeston, J.G., Nicolaides, K.A., Gosden, C.M., \& McGregor, A.M. (1991). Thyroid function in fetuses with chromosomal abnormalities. British Medical Journal, 302, 628.

Timbury, G.C., McGuire R.J. \& MacGillivray, R.C. (1963). The effect of anti-thyroid treatment on the mental functioning of a thyrotoxic mongol. American Journal of Mental Deficiency, 67, 822-826.

Tirosh, E., Taub, Y., Scher, A., Jaffe, M. \& Hochberg, Z. (1989). Short-term efficacy of thyroid hormone supplementation for patients with Down syndrome and low- borderline thyroid function. American Journal on Mental Retardation, 93, 652-656.

Toledo, C., Alembik, Y., Dott, B., Finck, S. \& Stoll, C. (1997). Anomalies of thyroid function in children with Down syndrome. Archives de Pediatrie, 4, 116-120.

Tonz, O. \& Trost, P. (1974). Juvenile hypothyreose und menstruatiopraecox bei Trisomie 21, linishe Padiatrie (Stuttigart). 186, 543-549.

Tunbridge, W.M.G., Evered, D.C. \& Hall, R. (1977). The spectrum of thyroid disease in a community: the Whickham survey. Clinical Endocrinology, 7, 481-493.

Ugazio, A., Jayakas, S., Marcioni, A., et al., (1977). Immunodeficiency in Down’s syndrome; relationship between presence of thyroglobulin antibodies and HBsAg carrier status. European Journal of Pediatrics, 126, 139-146.

Ugazio, A., Maccario, R. \& Burgio, G.R. (1992). Immunologic Features. In Pueschel and Pueschel (Eds.). Biomedical Concerns in Persons with Down Syndrome. Paul H Brookes Publishing Co. USA.

Vanhaelst, L., Hayez, F., Bonnyns, M. \& Bastenie, P.A. (1970).Thyroid autoimmune disease and thyroid function in families of subjects with Down's syndrome. Journal of Clinical Endocrinology, 30, 792-797.

Verma, I.C. \& Ghal, O.P. (1971). Hypothyroidism in children with mongolism. Indian Journal of Paediatrics, 38, 229-232.

Vladutiu, A.O., Chun, T.C., Victor, A., Gienau, L. \& Bannerman, R.M.(1984). Down's syndrome and hypothyroidism: A role for thyroid autoimmunity? Lancet i, 1416.

Werder, E.A., Torresani, T., Navratil, F., Arbenz, U., Eiholzer, U., Pelet, B., Burri, M., Schwarzenbach, P., Hunziker, U. (1993). Pericardial effusion as a sign of acquired hypothyroidism in children with Down syndrome. European Journal of Pediatrics, 152, 397-398. 
Williams, J.D., Summitt, R.L. \& Camacho, A.M. (1971). Hypothyroidism in children with the Down syndrome: Report of three cases. Birth Defects: Original Article Series, 7, 43-47.

Wisnewski, K.E., Cobill, J.M., Wilcox, C.B., Caspary, E.A., Williams, D.G. \& Wisnewski, H.M. (1979). T lymphocytes in patients with Down's syndrome. Biological Psychiatry, 14, 463-471.

Zergollern, L., Vukelic, G. \& Raos, M. (1974). Atireoza uz DownovSindrom. Medicinskihiv, 28, 429432.

Ziai, F, Rhone, D., Juctice, P. \& Smith, G.F. (1984). Thyroid function studies in children and adolescents with Down's Syndrome. Perspectives and Progress in Mental Retardation, 2, 243-250.

Zori, R.T., Schatz, D.A., Ostrer, H., Williams, C.A., Spillar, R. \& Riley, W.J. (1990). Relationship of autoimmunity to thyroid dysfunction in children and adults with Down syndrome. American Journal of Medical Genetics Supplement, 7, 238-241. 